\title{
Experiencing Higher Education by Afghan Refugees: A Case study from Pakistan
}

\author{
* Dr. Sadia Dilshad \\ ** Dr. Rukhsana Durrani, Lecturer (Corresponding Author) \\ *** Sehrish Javed, PhD Scholar
}

\begin{abstract}
(ब) $(\Theta$

The future of refugees in different countries is uncertain. They need support to provide hope for a successful future. Young refugees have their perspectives on the reflection of their personal experiences, needs, accessibility to services, and relevant opportunities. It is a common observation that most of the refugees remain silent regarding their experiences, feelings, and wishes during the journey of arrival in a new country. Nowadays, the voices of young refugees have been penned downed in literature; heard by practitioners, and by those who are involved in policymaking. For the current study, the objectives were to explore the experiences faced by Afghan refugees during their journey for higher education in Pakistan. This was a qualitative study and interview protocol was adopted as a tool for the collection of data. Data was collected through interviews with refugees' students by the researcher. 20 students were selected through purposive sampling technique from four higher education institutions of Khyber-Pakhtunkhwa in which 17 students were interviewed. Thematic analysis was done, and themes were generated from interviews. Through this study, it was recommended that the implementation of educational policies for refugees may be checked by the higher authorities so that young refugees may be facilitated in the journey of higher education.
\end{abstract}

Keywords: Experiences, Young Refugees, Settlement, Higher Education

Introduction

Although the life of refugees is not ideal throughout the world especially in third world countries, the future is the most uncertain and in a dire situation, which is endowed to young refugees as far as their families are concerned. They want to reflect the chance for more sustainable live lihood economically, educationally, and socially in the country where they are relocated and for their original country also. They try to reach the optimum level of expectations and cultivate critical thinking, skills, and knowledge capacities while getting educated. Mrsevic (2000) highlighted that peace is not the opposite of war but it is a creativity that can be considered as the opposite of war. It can be said that creativity is due to education that reduces conflicts and sustains settlement. Concerning various international conventions including the Universal Declaration of Human Rights (Article 26) it is evident that access to higher education is a human right even for the refugees, the convention on the rights of children (artic le 28c), and the international covenant on Economic, cultural right as well as social (Article 13c) (UNHCR, 2015). The protection from hurdles as well as obstacles and the contribution for post-conflict reconstruction, promotion of social-economical quality, and empowers refugee communities are the major recommendations for better settlements.

The upcoming security, as well as the well-being of refugees, is fundamentally linked with skills that are transferable along with the knowledge and capabilities that have been developed through education. With education, young refugees will be able to foresee their bright future and they will be able to contribute to the establishment of peaceful and stable societies in the future. However, obstacle due to displacement, lack of education, and other opportunities including skills and livelihood may force youth to resort to negative strategies that will ensure their position and the position of their families, the ir basic needs and by giving them new opportunities for opting of new risks in life (Government of Pakistan, 2016).

Education equips teachers as well as students with comparable tools that could help them to craft the future keeping in mind the unsettled present of an unsettled past. This reflects the importance of the role of education in the settlement of refugees. The researcher wants to explore the experience

\footnotetext{
* Islamabad Model College for Girls G9/4, Is lamabad Email: saadia.amjad@gmail.com

** Allama Iqbal Open University, Is lamabad Email: rukhsana.durrani@aiou.edu.pk

*** International Islamic University, Islamabad Email: sehrish.bilawar@gmail.com 
of young refugees regarding facts and myths of opportunities in Pakistan. With the increase in the challenges faced by refugees, the increase in the researches regarding the comparison of crosscountries needs time. The current study will extend imperial knowledge in the existing higher education experiences of young refugees in Pakistan

\section{Stateme nt of Problem}

There are approximately 21.3 million refugees around the globe (UNHCR, 2017), many of them find themselves in an unstable state of livelihood for years and years; they are unable to enjoy the ir full rights and they need to become self-sufficient and have to restart their lives again. Only an estimated 33 percent of Afghan refugees in Pakistan can read and write. Refugees need practical support and protection for their survival to excel in the field of education. However, the quality education, to refugee communities is not given by the government and donors in its true spirit. Only 2 percent of the donation is dedicated to education internationally (World Economic Forum, 2017). The basic hurdle to produce the potential educated refugees is the access of information to the potential opportunities(Lorisika, et al 2015). For refugee students debate about access to higher education takes into consideration the global context where the quality of education is not up to the mark. Despite the support of international conventions, barriers to higher education for refugees persist. Higher education can be used as a supportive element for the refugee crisis, moreover, it can play a significant role in helping to develop social as well as human necessities for the reconstruction of refugees' lives and communities. For this purpose, the current study intended to investigate the experiences faced by refugees at the higher education level.

\section{Objectives of the Study}

The objectives of this research were to find out the experiences faced by young refugees for adjustment in higher education during their educational careers.

\section{Research Questions}

The following research question was addressed:

1. What were the adjustment experiences of Afghan refugees faced for higher education in Pakistan?

2. How Afghan refugees adjust to different kinds of experiences they faced during the ir higher education in Pakistan?

\section{Re view of Related Literature}

Trauma increases the risk of lack of concentration and focus, which is crucial when learning a new language and taking education in the country you have come to (Watenpaugh, et al 2013). Together with the fact that for the most part refugees have a low level of education from their home country, this is one of the decisive reasons why refugees who live in Pakistan need to be provided with better education possibilities. Newly arrived refugees find it difficult to enter any education system due to many reasons. Firstly, they lack the entrance exam and therefore first need to spend time taking a 10th grade class and/or a full secondary-level education. Often it is very difficult to get the authorities to recognize the educational qualifications they have already gained from their home country. (Loris ika, et al 2015). The financial decline is coupled with an increase in the number of Afghan refugees, who are opting for voluntary repatriation as SSAR (Solutions Strategy for Afghan Refugees). SSR is successfully implemented, reinforcing the strategies of the (GOP) Government of Pakistan along with (GoA) Government of Afghanistan regarding strategies for voluntary management as well as the safe return of Afghan refugees. Despite hopes for an increase in return to the hometown numerous Afghan children remain in Pakistan due to the reason that the security situation continues to evolve in Afghanistan. The challenges in the host country have intensified with the arrival of a huge number of refugees (Koehler et al., 2018)

\section{Challenges faced by refugees}

Refugees are facing economic adjustment issues due to the reason that since 2016, it is observed that the funding through Pakistan programs to Afghan refugees has reduced with the overall reduction of foreign funding from UNHCR programs worldwide as the organization copes with the emergencies on multiple other fields. Another obstacle is to obtain the necessary documentation, which creates a hurdle for them to pursue their education. Education is vital for the refugees because I) it is a basic human right, ii) it is key for social and economic success iii) quality education can help refugees to overcome their troubles(Fazel, Reed, Panter-Brick, \& Stein, 2012). Refugee students often struggle to evidence for the attainment of their lost educational certificates as well as transcripts. Societal and 
educational adjustments of the refugees are one of the biggest obstacles that create a problem for them in their living. Providing safe learning environments, lifelong learning opportunities, and educational challenges with innovation connected with ICT where required is the main challenge. In KhyberPakhtunkhwa, Baluchistan and Punjab UNHCR have spent approximately 4,148,079 USD per year on educational support for the last five years. According to this report cost per child per year is 57 USD. Moreover, per child cost in Pakistan is estimated as 65 USD per year. Moreover, the lack of recognition of the ir educational documentation in other countries is also a big issue (Peterson \& Giles, 2010). The identity of refugee students may also have been lost (Peterson \& Giles, 2010; Lorisika et al 2015; UNESCO 2015b). To overcome these hurdles potential students, need to make lifethreatening journeys back to their hometowns to locate their needed documentation. In response to this sensitive issue, there is a need for initial guidance with new resources that are targeted at documenting recommended practices to help the institutions to recognize refugees applicants' beforehand learning in the case when verifiable or official documentation is missing (Loo, 2016).

Language adjustment is one of the key hurdles that creates a problem for young refugees to survive. The level of written and spoken the English language prevents many refugees from their success and creates a hurdle for them in the upcoming future (Lorisika, et al 2015). Refugee students have been out of education for several years and the ir education has been interrupted. Without proper preparatory courses, those students who are initially ready for higher education may not be able to restart their education (Dippo, et al 2012; UNESCO, 2015a).

\section{Refuge es' education strategy 2020-2022}

The first objective of refugee education strategy 2020 is access to quality primary, secondary and tertiary education. It also supports the Higher Education Commission for fee concessions at tertiary level institutions for refugees (UNHCR, 2019). This is the first objective regarding the issue but there are several challenges faced by the local government and the students. Such as in Pakistan, refugees face challenges of Poverty in families, Economic and social barriers that prevent retention and completion rates, and low retention rates. There is a high dropout rate due to socio-economic and quality issues. The insufficient access to quality education for refugees' children both secondary as well as tertiary education, insufficient opportunities for youth regarding their skill improvement, language, and curricula issues in the host country. Many students may have acquired the local language, which helps and permits them to undergo schooling but also avoids negative effects on a child's development.

\section{Conte mporary facilities of re fuge e's e ducation in Pakis tan}

According to the $18^{\text {th }}$ amendment in Pakistan free and compulsory education between age 5 to 16 (Article: Right to Education 25-A) is the right of all children. Still, Pakistan is not been able to meet Millennium Development Goal approved in 2015 for providing universal primary education for its population. For this purpose, Pakistan requires strategic support as well as a fully operational partnership with government other donning agencies to meet Sustainable Development Goal (number 4) which ensures 'inclusive and equitable quality education as well as lifelong learning opportunities for everyone, along with it corresponding education 2030 framework for action. Back in 2016, UNICEF, UNESCO, UNHCR, other partners along with the Federal Ministry of Education organized a consultation on SDGs \# 4 which has initiated with discourse and to build a common understanding of new agenda among provincial and national stakeholders. The consultation paved the way for provincial consultations that eventually results in the development of provincial and country-set targets and indicators for SDG \# 4. The federal ministry of education has constituted SDG \# 4, which is mandated to engage provinces to achieve country-specific targets and indicators. UNHCR misunderstands the situation regarding the implementation of Sustainable Development Goal No. 4. UNHCR is coordinating and collaborating with the cell of SDG \# 4 and making sure the targets of refugee education and reporting indicators. Moreover, they work closely with national and provincial authorities to develop strategic ways for the refugees and it guarantees their strategic ways for quality, access, and inclusive education. The coordination of UNHCR with the ministry of federal education, professional training, and other departments of ministry works well and emphasized 'equity and inclusion'. It connects with the education of refugees and it also seeks to ensure refugee children are provided with SDG \# 4. In addition to this, UNHCR keeps the spotlight on paragraph 11 of the Incheon declaration regarding education in the 2030 framework of action, where it is mentioned specifically for refugee education. UNDP, based on the UN system which has drafted a conceptual 
note on the mainstreaming the refugees is working for, acceleration as well as reporting the policy support for SDG. The concept note predicts the formation of inter-provincial as well as provincial forums regarding education. It is comprised of various committees to share and coordinate the required measures. These are initiatives that UNHCR remains attached to, to ensure the refugees' children as the focus of concern.

\section{Scholarships: Refugees students}

For the economic constraints, Fellowships, grants, and scholarships are offered to students outside the country wherever it is available, and universities are located. These are sometimes known as financial aids and the financial aid office of (UNHCR) the United Nations High Commissioner of Refugees runs it. The scholarships of UNHCR are available and offered by UNCHR for study and research. Various United Nations High Commissioners for Refugee scholarships, internships are available for international students. Other than university, based scholarships there are many other scholarships granted by organizations including trusts, corporate, etc. who offer scholarships, fellowships for international students. DAFI provides scholarships to Afghan refugee youth in Pakistan. The beneficiaries are mostly in the 19 to 30 years age group. Females range from 17 to 25 years whereas males range from 19 to 30 years. Most of the beneficiaries are from KPK, Baluchistan, Punjab, and Islamabad in Pakistan.

\section{Refuge es at higher education}

The higher education commission (HEC) has a clear policy about catering the refugee students. This policy consists of three parts. The first part grounds the issue by demonstrating the impetus for higher education for refugees, outlining the international conventions that call for refugees' participation in higher education, and providing enrolment data. The second part outlines the various barriers to access. In the third part, the paper identifies initiatives designed to increase higher education access for refugees.

For potential refugee students cost of pursuing higher education is also a hurdle. In the life of the majority of potential refugee students' economic hardship is the unaffordable fee of the institution (CRS, 2010; Dippo et al, 2012; RSC, 2014; Watenpaugh et al, 2014b; UNESCO 2015a). Particularly for urban refugees' information regarding opportunities that exist is also a challenge. Due to a variety of urban centers populations are dispersed, without sure information that communicates the opportunities which are open to them (Dryden \& Giles, 2010). This hurdle in the way of access is impaired due to lack of coordination between current providers which reflects that potential students must attempt to access information about multiple places with multiple initiatives This barrier to access is exacerbated by the lack of coordination between current providers, which means that potential students must attempt to access information about multiple initiatives in different places (AlFanar, 2015).

\section{Refuge es Hosting and Affected Areas (RAHA)}

For approximately, about the past four decades, Pakistan has been home to millions of Afghans. In 2009 RAHA program was initially launched between the Government of Pakistan (GOP) which is represented by EAD (Economic and Affairs Division), SAFRON (Ministry of States and Frontier Regions) in the Ministry of economic affairs and Statistics, a UN agencies consortium and numerous government and non-government agencies/organizations. It is a significant part of the Government's policy as well as management of Afghan nationals along w ith the key components of Afghan strategy solutions for the refugees during the years 2015-2017. In Pakistan, RAHA programs seek to improve social cohesion and co-existence and provide refugees with means and resources, which are predictable for a temporary stay. The vital aim of it is to complement individual humanitarian assistance with development, which is tangible investments while integrating the interventions into the government's programs on a national basis. There are about 144 educational projects which have been implemented with an estimated number of eleven thousand, five hundred beneficiaries by RAHA (UNHCR, 2011)

\section{Research Methodology}

The research design for the study was qualitative in nature based on interview protocols.

\section{Sampling}

For the current study, the purposive sampling technique was used to select the refugee students studying at higher educational institutions in Khyber Pakhtunkhwa. The reason for the selection of this type of sampling technique was to target only the refugee students studying at higher educations. 
For this purpose, four higher educational institutions were selected from Khyber Pakhtoonkhwa. For the selection of the students, the researcher first visits the higher educational institutions and gets the list of the Afghan refugee students from the administration department. 5 students were selected from each institution purposefully. Only those students were the part of the sample whose period as refugees was from 3 years to 10 years. In this way total of 20 refugee students' were approached and got data from 17 students because during interviews the level of saturation was achieved on 17 .

\section{Instrumentation}

After a thorough review of related literature, an interview plan was developed which consisted of questions related to the objectives of the research.

\section{Data Collection \&Analys is}

Data was collected by the researcher through personal visits to the required higher education institutions to directly contact the interviewee. The interviews were quit after interviewing 17 students when the level of saturation was achieved. The interviews were carefully studied and were transcribed. Themes were generated from these interviews. The analysis of interviews was based on themes generation on the qualitative pattern. These patterns involve identification, examination, then interpretation, and lastly, themes were generated from interview data. Later, it was determined how these themes and patterns help to answer the research questions. Step-wise analys is was done; firstly, initial coding was done based on common statements, then axial coding in which broad categories were made and at the end themes were generated.

\section{Results and findings}

Demographic data is as under which reflects the demographics of the 17 students whose data were collected:

\begin{tabular}{lll}
\hline S. No. & Time of stay (Approx.) & Background of Study \\
\hline 1 & 10 years & MS Political Science \\
2 & 10 years & MS Political Science \\
3 & 10 years & MA Education \\
4 & 9 years & MA Education \\
5 & 9 years & MA History \\
6 & 9 years & MA History \\
7 & 8 years & MA History \\
8 & 8 years & MA Economics \\
9 & 8 years & MBA \\
10 & 7 years & MBA \\
11 & 7 years & MBA \\
12 & 6 years & MBA \\
13 & 6 years & B. com. \\
14 & 5 years & BS Zoology \\
15 & 5 years & BS Sociology \\
16 & 3 years & BS IR \\
17 & 3 years & BS IR \\
\hline
\end{tabular}

The above table reflects that only 3 students stayed in Pakistan for 10 years as refugees and for9 years also 3 students while 3 students resided in Pakistan as refugees in the last 8 years. All these students reached to Master's level of education in different disciplines during the ir journey as a refugee.

Table 1: Higher Education experiences in the host country

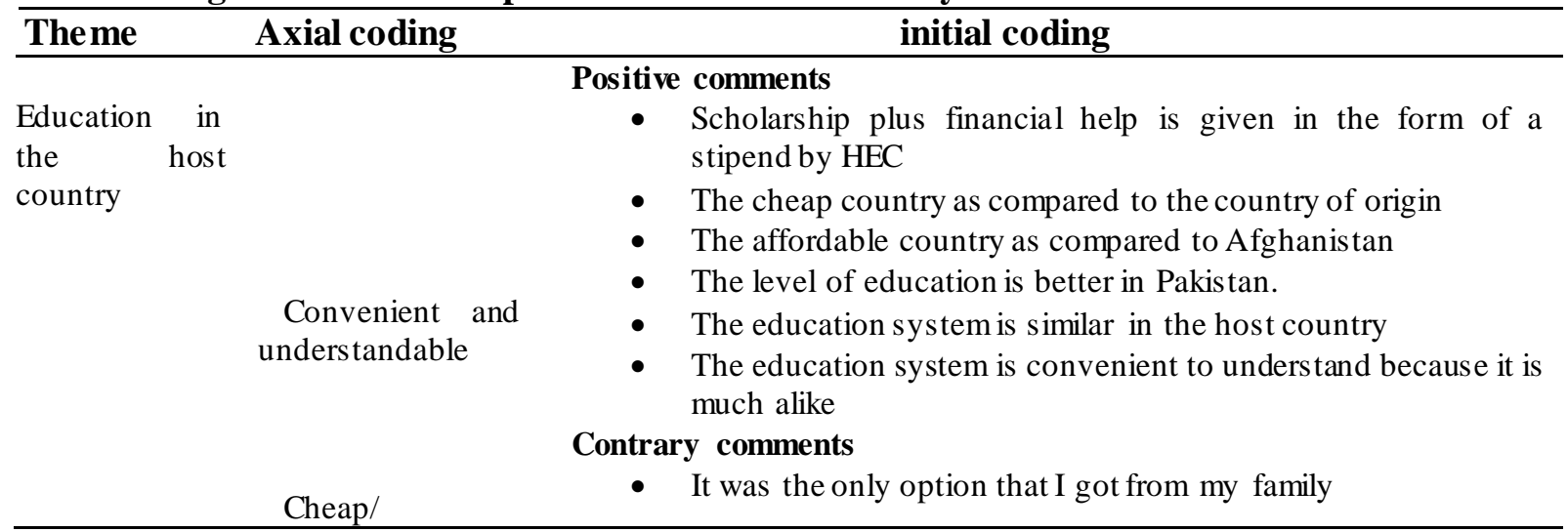




\begin{tabular}{l}
\hline affordable country $\begin{array}{c}\text { Facing inequality in the context of receiving up-gradation } \\
\text { opportunities }\end{array}$ \\
\hline Participants responded that they got admission to higher education because of numerous \\
reasons. Few participants were of the view that "they got a good scholarship as well as stipend by \\
Pakistan's Higher Education Commission". Others reflected that "Pakistan is a cheap country as \\
compared to their origin so for them it is easy to manage here." A couple of students highlighted that \\
"Pakistan is an affordable country for living and another reason for getting admission here is the \\
good education standard". However, others reflected that "daily usage stuff is quite expensive here in \\
contrast to their hometown because of which they find it difficult to live here". It was also narrated by \\
refugees that "it was easy for them to get admission and also easy in the context of understanding the \\
education system which is quite similar to that of their own country". Moreover, some other students \\
highlighted that getting admiss ion to Pakistan was the only option they had because of which they \\
came here. But after coming here they had a great experience. Students also expressed that Pakistan \\
being a neighbor brother country sometimes faces inequalities here in the areas where Pakistani \\
students get to benefit from opportunities.
\end{tabular}

Table 2: Economic adjustment experiences in the host country

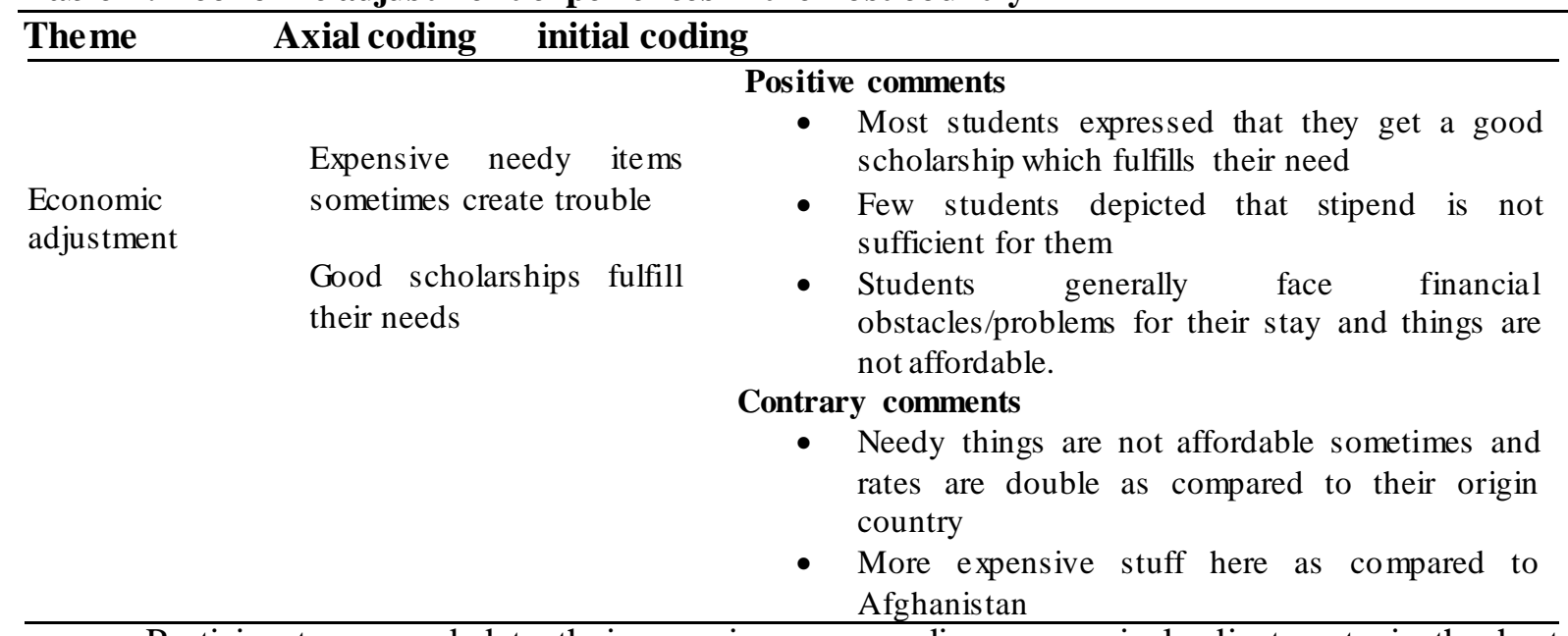

Participants responded to their experiences regarding economical adjustments in the host country that is Pakistan by saying that "in beginning, it was hard to adjust but now they are quite comfortable". Most of the students were happy in the context of economical adjustments because they have got a good stipend/ scholarship from the Higher Education Commission Pakistan. However, few of the students depicted that "stipend is not fulfilling their needs. Therefore, they are facing obstacles for the achievement of daily needed things". Students brought into consideration that daily usage stuff is expensive in the host country but they only had the option to buy the neediest things.

Table 3: Social adjustment experiences in the host country

\begin{tabular}{|c|c|c|}
\hline Theme & Axial coding & initial coding \\
\hline $\begin{array}{l}\text { Social } \\
\text { adjustment }\end{array}$ & $\begin{array}{l}\text { - Social values are } \\
\text { different in both the } \\
\text { countries }\end{array}$ & $\begin{array}{l}\text { Positive comments } \\
\text { - Social adjustment is not much difficult here } \\
\text { - A bit of similar cultural experiences in host countries } \\
\text { and seniors helped me with my adjustment here. } \\
\text { - Pakistan is a bit like Afghanistan in the context of the } \\
\text { social environment but not much friendly. } \\
\text { Contrary comments } \\
\text { - Here the social norms are more religious than } \\
\text { Afghanistan although both are Muslim countries. } \\
\text { - Social adjustment is a bit difficult because of } \\
\text { conservative people of the host country } \\
\text { - Afghani people are considered insecure most of the } \\
\text { time. }\end{array}$ \\
\hline
\end{tabular}

Students have contrary comments regarding social adjustments in the host country and most of the students replied that they didn't face much difficulty regarding social adjustment in the host country. The reason for this according to students is that the cultural values are somehow similar. Moreover, there is not much difference in the apparent look of Afghani or Pakistani people, so it 
became easy for them to become a part of Pakistani society easily. Others reflected that they faced difficulty for the ir social adjustment and seniors helped them with the ir early adjustments. The host country is somehow similar in the context of norms and taboos, but it is more religious although both countries are Muslim. Social adjustment sometimes becomes a bit difficult because people in the host country think of us as insecure humans/terrorists.

Table 4: Educational Adjustment in the host country

\begin{tabular}{|c|c|c|}
\hline Theme & Axial coding initial coding & \\
\hline $\begin{array}{l}\text { Educational } \\
\text { adjustment }\end{array}$ & $\begin{array}{l}\text { Quality of education } \\
\text { and a similar system of } \\
\text { education }\end{array}$ & $\begin{array}{l}\text { Positive comments } \\
\text { - The really helpful education system and having very } \\
\text { good experience of study here } \\
\text { - Scholarship plus financial help is given in the form of } \\
\text { a stipend } \\
\text { HEC cooperated in the admis sion procedure and other } \\
\text { things so it becomes easy for us to get a scholarship } \\
\text { here. } \\
\text { - The level of education is better in Pakistan. } \\
\text { The education system is similar in the host country } \\
\text { Contrary comments } \\
\text { It was tough to get admission to the host country and } \\
\text { we are not satisfied with the admission procedure } \\
\text { here. } \\
\text { Due to nationality barriers, we cannot connect with } \\
\text { other fellows and teachers because of which they } \\
\text { cannot clarify few unclear concepts. } \\
\text { We do not have good access to the open libraries } \\
\text { Language is also a problem in some places, but most } \\
\text { teachers speak in English, so it becomes easy for us to } \\
\text { understand the concept }\end{array}$ \\
\hline
\end{tabular}

Participants of the current study responded that the "education system in Pakistan is really helpful and they are having very good experience in the host country. We are facilitated with scholarships and stipends". Moreover, "Higher Education Commission cooperated in the admission procedure and it becomes easy for the Afghan students to get an education at a higher level in the host country". Few students reflected that level of education is better in Pakistan and the education system is similar in the host country. Some students reflected that it was tough to get admission to the host country, but the admission procedure is complicated. The experience of few other students reflected that due to nationality barriers we cannot connect with other fellows easily. Furthermore, students also highlighted that few teachers discriminate between nationalities because of which unclear concepts cannot be easily clarified in our minds. Another obstacle that students highlighted is that Afghan refugees do not have the same access to open libraries that of Pakistani nationals. Another problem faced by few students was a language issue but with time, it is not an issue.

Table 5: Communication/Language adjustment in the host country

\begin{tabular}{|c|c|c|c|}
\hline Theme & Axial coding init & ling & \\
\hline $\begin{array}{l}\text { Language/ } \\
\text { communicati } \\
\text { on } \\
\text { adjustment }\end{array}$ & $\begin{array}{l}\text { - Language/ } \\
\text { communication is } \\
\text { key for sharing } \\
\text { information as well } \\
\text { as ideas }\end{array}$ & $\begin{array}{l}\bullet \\
\bullet \\
\bullet\end{array}$ & $\begin{array}{l}\text { Positive comments: } \\
\text { Most of the time, language does not create a problem but } \\
\text { at the very start, it was much difficult to understand the } \\
\text { Urdu language. } \\
\text { Contrary comments: } \\
\text { The language was a big problem at some places, but most } \\
\text { teachers speak in English, so it becomes easy for us to } \\
\text { understand the concept } \\
\text { In the start language was the biggest is sue which creates a } \\
\text { hurdle in all walks of life. }\end{array}$ \\
\hline
\end{tabular}

In the experience of most of the student's language was an obstacle for communication at the start of the first year when students started their education. Most students reacted that language does not create a problem for them it did so when they came to Pakistan for the first few years. In the starting years, the Urdu language was a hurdle for their understanding of things. 


\section{Discussion and Conclusion}

The current study reflected the experiences as well as the perception of refugee students in the province of Khyber Pakhtunkhwa. The five themes were drawn based on data i.e., economic, social, language, and educational adjustment in the host country. The findings of the study revealed that most students lack the feeling of home in the host country but still they reported their satisfaction in the education system here. According to the participants it was easy for them to manage their education in the host country because of good stipend/scholarship was awarded by Higher Education Commission. This economic aid helped them in coping with an economic barrier in admission. Pakistan and Afghanistan be ing neighbor Muslim countries have different customs and in the perception of refugee students, Pakistan is a bit more religious as compared to their hometown. In this scenario, they expected equal rights in institutions but mostly not given to them as compared to the Pakistani students.

The reaction of students to economical problems was different; few reflected that stipend is not sufficient for them to fulfill all their basic needs and they have to depend on their parents for expenses. While few of them reflected that stipend/ scholarship is sufficient and the currency of Afghanistan is of more value than that of Pakistani rupee so they can manage their expenses easily. Regarding social adjustment, students were of the view that they do not face much difficulty in the social adjustment in the host country because cultural values are somehow similar in both countries. Moreover, wherever they face a difficult situation, their seniors help.

The majority of the students stated that the education system of Pakistan is similar to that of Afghanistan but here they can have the completion for progress so can have more exposure. Previous researches showed that for potential refugees, students' cost of pursuing higher education is also a hurdle. In the life of the majority of potential refugee students, one of the economic barriers is the unaffordable fee of the institution (CRS, 2010; Dippo et al, 2012; RSC, 2014; Watenpaugh et al, 2014b; UNESCO 2015a). However, for the current study, most of the students responded that the higher education commission in Pakistan is helpful in the context of education and students are having a very good experience. It was helpful for students to stay in Pakistan because of its good education system. Some students expressed their opinion that the admission process is difficult due to formalities made for refugees. Another research conducted by Peterson and Giles in 2010 reflected that another great hurdle is the struggle of refugee students for the attainment of their lost documentations and transcripts and lack of recognition in other countries. The same problem was reported by few in this research, but not by most.

Other obstacles that refugee students faced were related to the connectivity with other students in the host country because of nationality discrimination. Students expressed about language/communication barrier at the start of education but later they adjusted within the environment where Urdu and other languages were commonly spoken. Language was one of the major barriers, but they overcome it with time as they need to communicate for their daily life matters.

\section{Recommendations}

Following recommendations were made based on the findings of the current research:

1. The rules for refugees may be changed to make them flexible to accommodate the educational needs of refugees.

2. There is a need for strong measures which facilitate refugees all over the world for the attainment of their fundamental right to education.

3. There is the need for the formulation of rules at the International level for refugees based on ground realities to solve their educational problems, they are facing.

4. There is a need for continuous support in form of stipends and funds for refugees in the journey of education within the countries they are residing in.

\section{References}

Crul, M. (2017). 'Refugee children in education in Europe. How to prevent a lost generation?' (SIRIUS network policy brief series, issue no. 7). Retrieved from http://www.siriusmigrationeducation.org/wp-content/uploads/2018/10/Refugeechildren-in-education-inEurope.-How-to-prevent-a-lost-generation.pdf. 
Dippo, D., Orgocka, A. and Giles, W. (2012). Feasibility study report: Reaching Higher: The Provision of Higher Education for Long-Term Refugees in the Dadaab Camps, Kenya. The Borderless Higher Education for Refugees Partnership/York University, Toronto, Canada.

Dryden, S. and Giles, W. (2010). Higher Education for Refugees. Refuge Journal, 27(2). Retrieved from http//refuge.journals.yorku.ca/index.php/refuge/article/viewFile/34717/31547

Fazel, M., Reed, R. V., Panter-Brick, C., \& Stein, A. (2012). The mental health of displaced and refugee children resettled in high-income countries: Risk and protective factors. The Lancet, 379(9812), 266-282.

Koehler, C., Kakos, M., Sharma-Brymer, V., Schneider, J., Tudjman, T., Van den Heerik, A., Toumpoulidis, G. (2018). Multi-country partnership to enhance the education of refugee and asylum-seeking youth in Europe -PERAE (Comparative Report). SIRIUS - Policy Network on Migrant Education, Brussels. Retrieved from https://www.researchgate.net/publication/326113676_SIRIUSPolicy_Network_on_Migrant_Education_Multicountry_Partnership_To_Enhance_The_Educ ation_Of_Refugee_And_Asylum-Seeking_Youth_In_Europeperae_Comparative_Report.

Loo, B. (2016). Recognizing Refugee Qualifications: Practical Tips for Credential Assessment. WES Research.

Loris ika, I., Cremonini, L. and Safar Jalani, M. (2015). Study to Design a Programme/Clearinghouse Providing Access to Higher Education for Syrian Refugees and Internal Displaced Persons. European Union/PROMAN. https://www.utwente.nl/bms/cheps/news/finalreportstudyhigher educationsyrianrefugeesandidp.pdf

Mrsevic, Z. (2000). "The opposite of war is not peace - it is creativity". In Frontline feminisms: Women, war, and resistance, Edited by Waller, M. and Rycenga, J. 41-56. New York and London: Garland.

RSC, (2014). Ensuring a quality education for young refugees from Syria: a mapping exercise on quality education for young refugees from Syria (12 - 25 years). https://www.rsc.ox.ac.uk/ files/publications/other/rr-syria-youth-education-2014.pdf

UNHCR, (2016). Projected Global Resettlement Needs 2017. Geneva. http://www.unhcr.org/uk/ protection/resettlement/575836267/unhcr-projected-global-resettlement-needs-2017.html

UNHCR, (2019). Refugees Education Strategy Pakistan. Islamabad: UNHCR.

UNHCR, "Handbook for Emergencies, (2007) 3rd ed. (Geneva: UNHCR, 2007), 417.

Government of Pakistan, (2016), Pakistan Education Statistics 2015-16, available at http://library.aepam.edu.pk/Books/Pakistan\%20Education\%20Statistics\%202015-16.pdf [accessed 30 June 2017]

UNESCO (2015a). EU Jamiti Higher Education Initiative: Factsheets.

UNESCO (2015b). EU Jamiti Higher Education Initiative: Mapping of Higher Education Needs and Opportunities for Syrian Refugees in Jordan. Survey Report.

UN High Commissioner for Refugees (UNHCR), Missing Out: Refugee Education in Crisis, September 2016, available at: http://www.refworld.org/docid/57da83714.html (accessed 20 March 2020)

UN High Commissioner for Refugees (UNHCR), (2011). Population Profiling, Verification and Response Survey of Afghans in Pakistan, available at http://unhcrpk.org/wpcontent/uploads/2012/11/PPVR-Report.pdf (accessed 20 March 2020)

Watenpaugh, D. K., Fricke, A., and King, J. (2013). Uncounted and unacknowledged: Syrian refugee students and scholars in Jordan. IIE UCD. http://www.alnap.org/node/23039.aspx

Watenpaugh, D. K. Fricke, A. and King, J. (2014). We will stop here and go no further: Syrian University Students and Scholars in Turkey. Institute of International Education, UC Davis. http://www.iie.org/ /media/Files/Corporate/Publications/We-Will-Stop-Here-And-Go-NoFurther-Syrian-University-Students-And-Scholars-In-Turkey-002.pdf? la=en

World Economic Forum, (2017). The Global Competitiveness Report 2016-2017, available at https://www.weforum.org/reports/the-global-competitiveness-report-2016-2017 (accessed 20 March 2020) 